Model Rebels 
The publisher gratefully acknowledges the

generous contribution toward the publication of this book provided by the Wang Family Foundation. 


\section{Model Rebels}

The Rise and Fall of China's Richest Village

Bruce Gilley

UNIVERSITY OF CALIFORNIA PRESS

Berkeley Los Angeles London 
University of California Press

Berkeley and Los Angeles, California

University of California Press, Ltd.

London, England

(C) 200 I by the Regents of the University of California

\section{Library of Congress Cataloging-in-Publication Data}

Gilley, Bruce, I966-

Model rebels : the rise and fall of China's richest village / Bruce Gilley.

p. $\quad \mathrm{cm}$.

Includes bibliographical references and index.

ISBN 0-520-22532-5 (alk. paper) — ISBN o-520-22533-3 (pbk.: alk. paper)

I. Ta-ch'u chuang (China)_Economic conditions. 2. Yu, Zuomin-Political activity. 3. Crimes-China-Ta-ch'u chuang. 4. Peasantry-China-Ta-ch'u chuang. I. Title: Rise and fall of China's richest village. II. Title.

$\mathrm{HC}_{42} 8 . \mathrm{T}_{23} \mathrm{G}_{54} 2000$

330.95 I' $^{\prime} 54-\mathrm{dc} 2 \mathrm{I}$

$00-02232 \mathrm{I}$

Manufactured in the United States of America

$\begin{array}{llllllllll}9 & 8 & 7 & 6 & 5 & 4 & 3 & 2 & \text { I } & \text { O } \\ \text { I0 } & 9 & 8 & 7 & 6 & 5 & 4 & 3 & 2 & \text { I }\end{array}$

The paper used in this publication meets the minimum requirements of ANSI / NISO Z39 0.48-I992 (R I997)

(Permanence of Paper). $\circledast$ 
For Joyce 
This page intentionally left blank 